\title{
THEORETICAL INVESTIGATION OF EGYPT CLIMATE CONDITIONS ON THE PERFORMANCE OF PEM FUEL CELL
}

\begin{abstract}
Mohammed H. koura ${ }^{1}$ Salah H. El. Emam ${ }^{2}$, M. G. Mousa ${ }^{2}$ and A. A. Hegazi ${ }^{2}$
${ }^{1}$ Teaching Assistance, Higher Technological Institute Tenth of Ramadan City

${ }^{2}$ Mechanical Power Eng. Dept., Faculty of Engineering, Mansoura University

\section{ABSTRACT}

This paper describes a theoretical model to investigate effects of different air parameters on the performance of PEM fuel cell. Parameters taken into considerations in the study are air mass flow rate, pressure, temperature and relative humidity. This study is applied on a fuel cell with a across section area of $218 \mathrm{~cm}^{2}$ stacked in a series of combined 110 cells. The observed effects on the fuel cell performance are presented as system power, efficiency and polarization curves. The stacked cells may produce an overall power output more than $20 \mathrm{~kW}$, this model studies the effects in two cases the first with constant relative humidity effect, and the second with different relative humidity effect. This model monitor the effects on PEMFC performance by using the V-I polarization curves. It showed that with the increase of air pressure, temperature and relative humidity the power increases nearly up to $8 \%$, in the other hand with the increase of air flow rate the performance is decreasing.
\end{abstract}

\begin{tabular}{|c|c|c|}
\hline \multicolumn{3}{|c|}{$\begin{array}{l}\text { Keywords: PEMFC, Transient, polarization curves, Relative humidity. } \\
\text { Nomenclature }\end{array}$} \\
\hline A & Cell cross section area & $\mathrm{m}^{2}$ \\
\hline AveCell & Average voltage of stack cells & V \\
\hline$E^{O C V}$ & Open circuit voltage of a hydrogen /oxygen fuel cell & $\mathrm{V}$ \\
\hline$E^{O}$ & Fuel cell voltage at standard conditions & V \\
\hline$F$ & Faraday's constant $=96.48533289$ & $\mathrm{C} / \mathrm{kmol}$ \\
\hline$I$ & Cell current & A \\
\hline$I_{m c}$ & Current consumed by air compressor & A \\
\hline$i_{\mathrm{o}_{2}}^{o}$ & $\begin{array}{l}\text { Apparent exchange current density of } \mathrm{O}_{2} \text { reduction } \\
\text { reaction on Pt catalyst }\end{array}$ & $\mathrm{A} / \mathrm{m}^{2}$ \\
\hline$I_{O_{2(P t)}}^{O}$ & Intrinsic exchange current density & $\mathrm{A} / \mathrm{m}^{2}$ \\
\hline$J_{\text {cell }}$ & Cell current density & $\mathrm{A} / \mathrm{m}^{2}$ \\
\hline$J_{d v}^{f}$ & $\begin{array}{l}\text { Apparent diffusion limiting current density for the } \\
\text { cathode } \mathrm{O}_{2} \text { reduction reaction }\end{array}$ & $\mathrm{A} / \mathrm{m}^{2}$ \\
\hline$\dot{m}_{\text {air }, \text { feed }}$ & Air mass flow rate feed in cell & $\mathrm{kg} / \mathrm{s}$ \\
\hline$\dot{m}_{H_{2} f \text { e日d }}$ & Hydrogen mass flow rate feed in cell & $\mathrm{kg} / \mathrm{s}$ \\
\hline$M_{\text {air }}$ & Molar mass of air & $\mathrm{kg} / \mathrm{mol}$ \\
\hline
\end{tabular}




\begin{tabular}{|c|c|c|}
\hline$M_{o_{2}}$ & Molar mass of oxygen & $\mathrm{kg} / \mathrm{mol}$ \\
\hline$\dot{m}_{O_{z, \text { consumed }}}$ & Consumed oxygen mass flow rate & $\mathrm{kg} / \mathrm{s}$ \\
\hline$\dot{\boldsymbol{m}}_{H_{2, \text { consumed }}}$ & Consumed hydrogen mass flow rate & $\mathrm{kg} / \mathrm{s}$ \\
\hline$\dot{m}_{\text {cathode, out }}$ & Mass flow rate of air from cathode outlet & $\mathrm{kg} / \mathrm{s}$ \\
\hline$\dot{m}_{H_{2} O, p r o d}$ & Amount of product water in the cell & $\mathrm{kg} / \mathrm{s}$ \\
\hline $\mathrm{n}_{\text {cells }}$ & Number of cells in fuel cell stack & cells \\
\hline$\dot{n}_{\text {feed }}$ & Mole flow rate of reactant feed & $\mathrm{kmol} / \mathrm{sec}$ \\
\hline$\dot{n}_{\text {consumed }}$ & Mole flow rate of reactant consumed & $\mathrm{kmol} / \mathrm{sec}$ \\
\hline$\eta_{\mathbf{c}}$ & Cathode over-potentials & V \\
\hline$\eta_{\mathbf{a}}$ & Anode over-potentials & $\mathrm{V}$ \\
\hline$\eta_{\mathbf{m}}$ & Membrane resistance polarization & A. $\Omega$ \\
\hline$n_{a o}$ & $\begin{array}{l}\text { Electron transfer number in the determining step of the } \\
\mathrm{O}_{2} \text { reduction reaction }\end{array}$ & \\
\hline$P_{\text {air }}$ & Air pressure & atm \\
\hline$P_{o_{2, i n}}$ & Partial pressure of oxygen & atm \\
\hline$P_{H_{2 \text { in }}}$ & Partial pressure of hydrogen & atm \\
\hline $\mathbf{P}_{\text {gross }}$ & Gross power out of fuel cell & $\mathrm{W}$ \\
\hline $\mathbf{P}_{\text {net }}$ & Net power out of fuel cell & W \\
\hline $\mathbf{P}_{e l}$ & Electric stack power. & $\mathrm{W}$ \\
\hline $\mathbf{P}_{\text {thermal }}$ & Thermal stack power & $\mathrm{W}$ \\
\hline $\mathbf{P}_{H_{2, H H V}}$ & Chemical power of hydrogen flow for $\mathrm{HHV}$ & W \\
\hline $\mathbf{P}_{H_{2} \text {,consumed }}$ & Consumed hydrogen power & $\mathrm{W}$ \\
\hline $\mathbf{P}_{\text {compressor }}$ & Power consumed by air compressor & $\mathrm{W}$ \\
\hline $\mathbf{P}_{\text {fuel, consumed }}$ & Fuel consumed power & $\mathrm{W}$ \\
\hline$P_{\mathrm{H}_{2} \mathrm{O}}$ & Saturated water vapor pressure & atm \\
\hline$P_{H_{2} O}^{O}(T)$ & Saturated water vapor pressure at $T$ & atm \\
\hline RH & Relative humidity of air & $\%$ \\
\hline $\mathrm{R}$ & Universal gas constant $=8.314$ & $\mathrm{~kJ} / \mathrm{kmol} . \mathrm{K}$ \\
\hline$R_{m}$ & Membrane resistance & $\Omega . \mathrm{m}^{2}$ \\
\hline$T_{\text {cell }}$ & Temperature of the fuel cell & $\mathrm{K}$ \\
\hline$V_{\text {cell }}$ & Voltage for a single fuel cell & V \\
\hline$V_{\text {stack }}$ & Voltage of the entire fuel cell stack & $\mathrm{V}$ \\
\hline$V_{\text {bus }}$ & Voltage consumed by air compressor & $\mathrm{V}$ \\
\hline$X_{\mathrm{on}_{\mathrm{z}}}$ & Mole fraction of $\mathrm{O}_{2}$ in air & \\
\hline$\frac{-\partial V_{\text {cell }}}{\partial I_{\text {cell }}}$ & $\begin{array}{l}\text { Ac impedance of the fuel cell at an ac frequency of } \\
\text { zero }\end{array}$ & \\
\hline
\end{tabular}

\section{Greek Symbols}


$\begin{array}{lll}\lambda_{\text {cathode }} & \text { Stoichiometric ratio for fuel cell cathode } & \% \\ \lambda_{\text {anode }} & \text { Stoichiometric ratio for fuel cell anode } & \%\end{array}$

$\begin{array}{cl}\text { Abbreviation } & \\ \text { ANFIS } & \text { Adaptive neural- Networks fuzzy infer system } \\ \text { AECD } & \text { Apparent exchange current density } \\ \text { CFD } & \text { Computational fluid dynamic model } \\ \text { EPSA } & \text { Cathode electrochemical Pt surface area } \\ \text { GC Tool } & \text { A comprehensive system design and analysis tool for fuel cell } \\ & \text { and other power systems. } \\ \text { IECD } & \text { Intrinsic exchange current density } \\ \text { LDVs } & \text { Light duty vehicles } \\ \text { LMBP } & \text { Levenberg- Marquardt BP } \\ \text { MCFC } & \text { Molten carbonate fuel cell } \\ \text { MEA } & \text { Membrane- Electrolyte- Assembly } \\ \text { OCV } & \text { Open circuit voltage } \\ \text { PEMFC } & \text { Proton exchange membrane fuel cell } \\ \text { PAFC } & \text { Phosphoric acid fuel cell } \\ \mathrm{P}_{\mathrm{t}} & \text { Platinum } \\ \text { SOFC } & \text { Solid oxide fuel cell } \\ \text { SR } & \text { Stoichiometric ratio } \\ \text { UAVs } & \text { Unmanned aerial vehicles } \\ \text { UUVs } & \text { Unmanned undersea vehicles }\end{array}$

\section{INTRODUCTION}

Fuel cells are electrochemical devices that convert the chemical energy of a reaction directly into electrical energy. Among the several types of fuel cell, Proton Exchange Membrane Fuel Cell (PEMFC) is a suitable choice for distributed energy sources, due to it is a high quality green energy source and it is gaining much attention because of its light weight, compact size, low maintenance, high efficiency and reliability. It serves as a potential source for electric power generation for standalone as well as for grid-tied applications. Compared with the other types of fuel cells, PEMFC shows promising results with its advantages such as low temperature, high power density, fast response, and zero emission if it is run with pure hydrogen, and it is suitable for use in portable power supply, vehicles, and residential and distributed power plants. In this paper a mathematical model is developed to calculate the effects of air transients in delivery system of a PEMFC on its performance.

\section{LITERATURE REVIEW}

In the most recent decade, fuel cells have been the primary research subject for a lot of specialists. Because of its potential for both transportation and stationary power applications, the Proton Exchange Membrane Fuel Cell (PEMFC) has been the concentration of a large number of these studies as a reasonable substitution for the aging internal combustion engines. The performance of a PEMFC is influenced by its operating condition parameters, which includes mass flow rate, pressure, temperature and humidity of the inlet gases. These variables influence the membrane water content, which influences fuel cell performance. 
The following prior research related with the effects of operating conditions, including air condition parameters on PEMFC performance. According to design and construction of PEMFC, Ogburn et al. [1] described the design and construction of a fuel cell hybrid electric vehicle based on the conversion of a five passenger production sedan. The vehicle utilized a moderately little small fuel cell stack to give average power requests, and a battery pack to give top power requests to changed driving conditions. Ferguson and Ugursal. [2] .studied a quasi steady state model for cogeneration of PEMFC power module systems created for use in coordinated building simulation. The model could anticipate the fuel cell system fuel usages, and heat and electricity production in response to building loads. Bird [3], presented a method to calculate the transient effects in a fuel cell air delivery system. This technique was used for a model of a $(20 \mathrm{~kW})$ car fuel cell system that was utilized as a part of Animul H2, a fuel cell-battery hybrid vehicle. The majority of this work was to develop a procedure to test the air delivery system to analyze the progression of the PEMFC system, Nielsen et al. [4], concentrated on modeling and optimization of the whole fuel cell system. This study was centered on building up a model of a PEMFC stack and to incorporate it with the external system required for providing the right conditions for a PEMFC. Tao et al. [5], analyzed the characters of the PEMFC; and used the approach and self-study about capacity of simulated neural networks to assemble the model of the nonlinear system, and used the Adaptive Neural-Networks Fuzzy Infer System (ANFIS) to make the temperature model of PEMFC which was used as the reference model of the control system, and adjusted the model parameters to control it online. Si-jia et al. [6], analyzed the need of the PEMFC generation development, and a short time later displayed the creating standard from four points of view: electrodes, single cell, stack, system; and then used the approach and self-study ability of artificial neural network to build the model of nonlinear system, and balanced the Levenberg-Marquardt BP (LMBP) to build the electric characteristic model of PEMFC. Spiegel. [7], presented that energy components were predicted to be the power delivery devices of the future. The developed model was made by MATLAB. Additional work performed for this work consolidated a numerical model for reckoning bolt torque, and plan and manufacture of four fuel cell stacks ranging in size from macro to micro scale for model validation. Seyezhai et al. [8], built up a numerical model of 750W PEMFC was created. This model delineates the conduct of PEMFC under steady-state and transient conditions. The simulation results procured using the proposed model establishes a foundation in designing controllers for fuel cell based for power generation applications. Ziogou et al. [9], presented a dynamic model of a PEM control module system which relies on mass and energy conservation equations consolidated with equations having experimentally characterized parametric coefficients subsequently bringing about a semi-empirical dynamic model. The study focused on the usage of the created model for deriving flexible design options and real-time control arrangements. Boscaino et al. [10], illustrated a steady state and dynamic modeling approach for PEMFC. The proposed model includes high efficiency and precision regardless of the possibility that the technology was quite simple and very suitable for implementation on any software. Santarelli et al. [11], depicted an approach for the estimation of a some parameters of the model of the polarization curve of the cell, additionally investigated and discussed the behavior of the parameters versus a fundamental variable (the cell working temperature). According to PEMFC water management and humidity modeling, Zhao et al. [12] developed a fuel cell system model for optimizing the operation of the fuel cell system. The design parameters of the stack and the estimating of the air supply and the water and thermal management subsystems were chosen to augment the system efficiency. Shimpalee et al. [13] developed a threedimensional flow simulation for PEMFC in which the addition of diffusion layers in both anode and cathode demonstrated the mass transportation behavior brought caused by inlet velocity, chemical reactions, and permeability of the diffusion layers. Song et al. [14] considered the performance of a Nafion 112 based proton exchange membrane (PEM) fuel cell at a temperature range from $23{ }^{\circ} \mathrm{C}$ to $120{ }^{\circ} \mathrm{C}$. Zhang et al. [15] calculated the relative humidity (RH) connection to water balance inside a fuel cell and several equations were presented as a function of fuel cell gas stream inlet and outlet pressures, inlet RHs, temperature, pressure drops across flow channels, and reactant partial pressures.

\section{AIM OF THE STUDY}

The objective of this study is to build up a model to control and analyze all vital operating parameter conditions of air flow transients for efficient PEMFC. Additionally it means to adjust the cell 
operating conditions to accomplish a comprehensive analysis of air flow rate, pressure, temperature and relative humidity and their consequences for PEMFC performance and its optimization to an adequate approach. The PEMFC air operating parameters are $(1.0315: 15$ bar $)$ pressure, $\left(40: 80{ }^{\circ} \mathrm{C}\right)$ temperature, $\left(20: 50 \times 10^{-3} \mathrm{~kg} / \mathrm{s}\right)$ mass flow rate and $(30: 100 \%)$ relative humidity.

\section{BASIC OPERATION OF PEMFC}

PEMFC primarily consists of three components: a negatively charged electrode (cathode), a positively charged electrode (anode) and a solid polymer electrolyte membrane. Hydrated hydrogen gas is supplied at the anode and air is supplied at the cathode. At the anode, hydrogen gas in the presence of the platinum catalyst is ionized into positively charged hydrogen ions and negatively charged electrons.

The reaction at the anode side is:

$2 \mathrm{H}_{2}=>4 \mathrm{H}^{+}+4 \mathrm{e}^{-}$

Cathode side:

$\mathrm{O}_{2}+4 \mathrm{H}^{+}+4 \mathrm{e}^{-}=>2 \mathrm{H}_{2} \mathrm{O}$

Net reaction:

$2 \mathrm{H}_{2}+\mathrm{O}_{2} \Rightarrow 2 \mathrm{H}_{2} \mathrm{O}$

The polymer membrane permits only positively charged hydrogen ions to flow from the anode to the cathode as shown in Fig. 1.

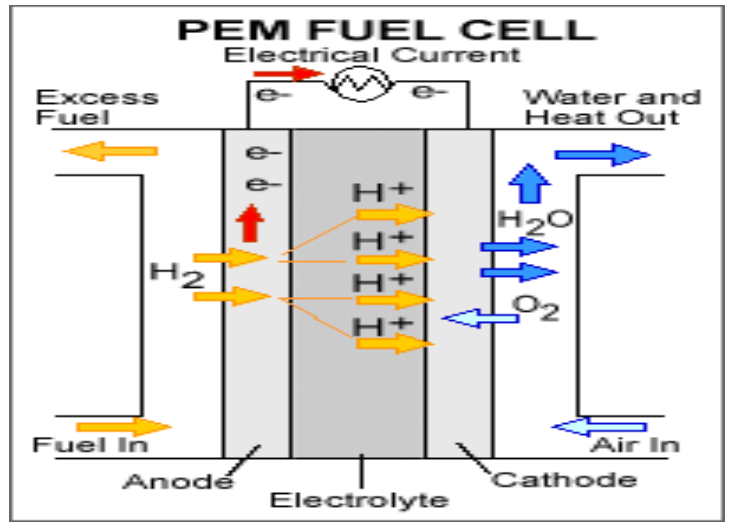

Fig. 1 Basic operation of PEMFC [16]

The PEMFC have a robust design and are relatively easy to build. A single fuel cell produces an open-circuit voltage of $(0.7$ to $1.0 \mathrm{~V})$.Several fuel cells are electrically connected in series forming a stack which provides a fairly large power at higher voltage and current levels. In this model the system inputs are air pressure, mass flow rate, and air temperature. The model calculates the effects of these parameters on system outputs. All of these outputs are monitored by using the (V-I characteristic curves) polarization curves which measure the performance of PEMFC. That for the operation of section I, for section II the input parameters are calculated with the addition of relative humidity parameter effect at different values and system outputs are illustrated by polarization curves.

\section{MODELING OF PEMFC}

Different models of PEMFC are reported in the literature [1].This paper consideration the main operational parameters focuses on model of fuel cell system intended for the usage of power generation application. The model is based on electrochemical equations that take into of fuel cell such as the operational air pressure, air mass flow rate, air temperature and air relative humidity. It depicts how the output power, efficiency and polarization curves of fuel cell are affected due to changes in load. The proposed model is simulated using MATLAB and it is used to analyze the transient behavior of the fuel cell. The V-I characteristics (polarization curves) of the PEMFC are obtained for different values of input variables. 


\section{MODEL EQUATIONS}

The GC Tool equation [17] is used to approximate the polarization curve of the fuel cell and to relate the outlet pressure and the air mass flow rate to the voltage and current out of the fuel cell. Polarization curves or the GC Tool equation [17] was used. The GC Tool equation [17] for fuel cell voltage is

$V_{\text {cell }}=1.05-0.055 \log \left(1000 J_{\text {cell }}\right)-\left(1.0604-2.493 \times 10^{-3} T_{\text {cell }}\right) J_{\text {cell }}+0.055 \log \left(P_{\mathrm{O}_{2}, \mathrm{in}}\right)$

Where $V_{\text {cell }}$ is the voltage for a single fuel cell, $J_{\text {cell }}$ is the current density, $T$ is the temperature of the fuel cell, and $P_{\boldsymbol{O} \text {, in }}$ is the partial pressure of oxygen. The equation relating the air mass flow to the fuel cell current $[18]$ is

$I=\frac{4 \times \mathrm{m}_{\text {air }} \times F \times \chi_{O_{2}}}{n_{\text {cells }} \times \lambda_{\text {cathode }} \times M_{\text {air }}}$

Where $I$ is the current out of the fuel cell, $\dot{\mathrm{m}}_{\text {air }}$ is the mass flow rate of air, $F$ is Faraday's constant, $\chi_{\mathrm{O}_{2}}$ is the mole fraction of $\mathrm{O}_{2}$ in air, $\mathrm{n}_{\text {cells }}$ is the number of cells in the fuel cell stack, $\lambda_{\text {cathode }}$ is the stoichiometric ratio for the cathode, and $M_{a i r}$ is the molar mass of air.

The current density $J_{\text {cell }}[18]$ is

$J_{\text {cell }}=I / A$

Where $J_{\text {cell }}$ is the current density, $I$ is the fuel cell current, and $A$ is the cross section area of the fuel cell stack.

The fuel cell stack voltage [18] is

$\mathrm{V}_{\text {stack }}=\mathrm{V}_{\text {cell }} \times \mathrm{n}_{\text {cells }}$

Where $V_{\text {stack }}$ is the voltage of the entire fuel cell stack, $V$ is the voltage of a single cell of the fuel cell stack, and $n_{\text {cells }}$ is the number of cells in the fuel cell stack. The gross power out of the fuel cell stack [18] is

$\mathrm{P}_{\text {gross }}=\mathrm{V}_{\text {stack }} \times I$

Where $P_{\text {gross }}$ is the gross power out of the fuel cell stack, $V_{\text {stack }}$ is the fuel cell stack voltage, and $I$ is the fuel cell current. The net power out of the fuel cell stack [18] is

$\mathrm{P}_{\text {net }}=\mathrm{P}_{\text {gross }}-I_{m c} \times V_{\text {bus }}$

Where $P_{n e t}$ is the net power out of the fuel cell system, $P_{\text {gross }}$ is the gross power out of the fuel cell stack, $I_{m c}$ is the motor controller current, and $V_{b u s}$ is the voltage of the motor controller battery pack. The net power out of the fuel cell system is the primary output from the model.

The stoichiometry $\lambda$ defines the ratio between reactant feed (into the fuel cell) and reactant consumption (inside the fuel cell). Due to fuel cell design and water management issues etc. the stoichiometry must always be more than one:

$\lambda=\frac{\dot{\mathrm{n}}_{\text {feed }}}{\dot{\mathrm{n}}_{\text {consumed }}}>1$

The reactant feed for $\mathrm{H}_{2}$ and air into the fuel cell stack are now defined by an anode and cathode stoichiometry $\lambda$, the mass flow for stack anode and cathode inlet are therefore [18]:

$\mathrm{m}_{H_{2} \text { Jfe日d }}=\frac{I N}{2 F} \cdot \lambda_{\text {anode. }} . M_{H_{2}}$ 
$\dot{\mathrm{m}}_{\text {air }{ }^{u f e \theta d}}=\frac{I N}{4 F_{0} \mathrm{XO}_{\mathrm{z}}} \cdot \lambda_{\text {cathode }} \cdot M_{\text {air }}$

Where $\chi_{O_{2}}$ is the oxygen content in air and $M$ is the molar weight.

The dry mass gas flow at stack cathode outlet contains less oxygen than air and is calculated as [18]:

$\mathrm{m}_{\text {cathode, out }}=\frac{L, N}{4 F} \cdot\left(\frac{\lambda_{\text {cathode }}}{x O_{2}} \cdot M_{\text {air }}-M_{O_{2}}\right)$

The amount of product water mass is equal to hydrogen consumption [18] and given by:

$\dot{\mathrm{m}}_{H_{2} O, p r o d}=\frac{L, N}{2 F} \cdot M_{H_{2} O} \quad\left[\dot{m}_{H_{2} O}\right]=\frac{g}{s e c}$

Electric stack power $P_{e l}$ is the product of stack voltage and stack load, also called gross power [18]:

$\mathrm{P}_{e l}=U_{\text {stack }} \cdot I=$ AveCell $. N . I$

Where AveCell $=U_{\text {Stack }} / \mathrm{N}$ is the average single cell voltage.

Thermal stack power $P_{\text {therm }}$ is that part of the consumed chemical fuel power which is not converted into electric power [18]:

$\mathrm{P}_{\text {therm }}=\mathrm{P}_{H 2, H H V}-\mathrm{P}_{\text {el }}$

For the hydrogen fuel cell it is defined based on HHV as [18]:

$\mathrm{P}_{\text {therm } m_{s} H V}=(1.481 \mathrm{~V}-$ AveCell $) . N . I=\mathrm{P}_{e l}\left(\frac{1.481 \mathrm{~V}}{\text { AveCell }}-1\right)$

Electric efficiency of a fuel cell (stack) is defined as [18]:

$\mathrm{\eta}_{\text {el }}=\frac{\mathrm{P}_{e l}}{\mathrm{P}_{\text {fuel, }} \text { consumed }}$

Where $\mathrm{P}_{\text {fuel, consumed }}$ is calculated by [18]:

$\mathrm{P}_{\text {fuel, consumed }}=1.481 \mathrm{~V} . \mathrm{N}$. I

Humidity calculations for the system [15]

$R H \%=\frac{P_{H_{2} O} O}{p_{H_{2} O}^{O} O(T)} X 100$

Where $P_{H_{2} O}^{o} O(T)$ can be expressed as a function of temperature $[19,20]$

$$
\begin{aligned}
P_{\mathrm{H}_{2} O}^{O} O(T) & =6.02724 \times 10^{-3}+4.38484 \times 10^{-4}(\mathrm{~T}-237.15)+1.39844 \times 10^{-5}(\mathrm{~T}-273.15)^{2} \\
& +2.71166 \times 10^{-6}(\mathrm{~T}-273.15)^{3}+2.57731 \times 10^{-9}(\mathrm{~T}-273.15)^{4}+2.82254 \times 10^{-11}(\mathrm{~T}-273.15)^{5}
\end{aligned}
$$

For a fuel cell inlet feed stream, the partial pressure of $\mathrm{O}_{2}$ (cathode stream) or $\mathrm{H}_{2}$ (anode stream) can be expressed as equation (22) or (23) [21]:

$$
\begin{aligned}
& P_{O_{2}}^{c \text {-inlet }}=\frac{1}{4,67}\left(P_{c}^{\text {inlet }}-P_{H_{2} O}^{O} R H_{c}^{\text {inlet }}\right) \\
& P_{H_{2}}^{a-\text { inlet }}=\left(P_{a}^{\text {inlet }}-P_{H_{2} O}^{O} R H_{a}^{\text {inlet }}\right)
\end{aligned}
$$

For a fuel cell outlet feed stream, the partial pressure of $\mathrm{O}_{2}$ (cathode stream) or $\mathrm{H}_{2}$ (anode stream) can be expressed as equation (24) or (25) [21]:

$$
P_{O_{2}}^{c-\text { outlet }}=\frac{1}{4.67}\left(P_{c}^{\text {outlet }}-P_{H_{2} O}^{O} R H_{c}^{\text {outlet }}\right)
$$


$P_{H_{2}}^{a-\text { outlet }}=\left(P_{a}^{\text {outlet }}-P_{H_{2} O}^{O}\right.$ R $\left.H_{a}^{\text {outlet }}\right)$

Thermodynamically, the open circuit voltage (OCV) of a hydrogen/oxygen fuel cell can be expressed as a Nernst equation as follows [21]:

$E^{O C V}=E^{O}+\frac{R T}{2 F}\left[\ln \left(P_{H_{2}}^{a-i n l e t}\right)+\frac{1}{2} \ln \left(P_{O_{2}}^{c-i n l e t}\right)\right]$

Where $\mathrm{E}^{\mathrm{OCV}}$ is the fuel cell voltage at $\mathrm{OCV}$, and $\mathrm{E}^{0}$ is the fuel cell voltage at standard conditions. The measured fuel cell voltage $\left(\mathrm{V}_{\text {cell }}\right)$ can be expressed as the following equation [15 and 22]:

$\mathrm{V}_{\text {cell }}=\mathrm{E}^{\mathrm{OCV}}-\eta_{\mathrm{c}}-\eta_{\mathrm{a}}-\eta_{\mathrm{m}}$

Where $\eta_{\mathrm{c}}$ and $\eta_{\mathrm{a}}$ are the cathode and anode over-potentials, respectively, and $\eta_{\mathrm{m}}$ is the membrane resistance polarization. $\eta_{\mathrm{c}}$ and $\eta_{\mathrm{a}}$ can be defined by Butler-Volmer and mass diffusion theories (for details, see [14]). This equation in case of low polarization range $\left(\eta_{c}<30 \mathrm{mV}\right)$ can be approximately expressed as:

$V_{\text {cell }}=E^{O C V}-\frac{R T}{n_{\text {coo }} F i_{O_{2}}^{O}} \cdot J_{\text {cell }}-J_{\text {cell }} R_{m}$

At a high polarization range, Eq. (28) can be approximately expressed as Eq. (29) [14]:

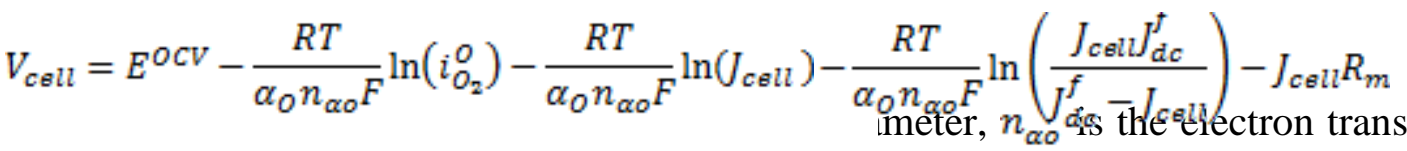

determining step of the $\mathrm{O}_{2}$ reduction reaction, $i_{O_{2}}^{O}$ is the apparent exchange current density of $\mathrm{O}_{2}$ reduction reaction on Pt catalyst, $I_{d e}^{f}$ is the apparent diffusion limiting current density for the cathode $\mathrm{O}_{2}$ reduction reaction, and $\mathrm{Rm}$ is the membrane resistance. If Equation (29) is differentiated against current density $\left(J_{\text {coll }}\right)$, the following ac impedance equation is obtained [24]:

$-\frac{\partial V_{c e l l}}{\partial I_{c e l l}}=\frac{R T}{\alpha_{O} n_{c o s} F} \frac{1}{J_{c e l l}}+\frac{R T}{\alpha_{O} n_{c o s} F} \frac{J_{d c}^{f}}{J_{c e l l}\left(O_{d c}^{f}-J_{c e l l}\right)}+R m$

$-\partial V_{c E l l} / \partial I_{c \theta l l}$ is the whole ac impedance of the fuel cell at an ac frequency of zero, the first righthand term in equation (29) is the reaction kinetic resistance (or charge transfer resistance), which can be expressed as $\mathrm{R}_{\mathrm{t}}$, where:

$\mathrm{R}_{\mathrm{t}}=\left(\mathrm{RT} / \alpha_{\mathrm{O}} \mathrm{n}_{\alpha, 0} \mathrm{~F}\right)(1) /\left(J_{\text {cell }}\right)$

The second term is the mass transfer resistance, which can be expressed as $\mathrm{R}_{\mathrm{mt}}$, where:

$\mathrm{R}_{\mathrm{mt}}=\left(\mathrm{RT} / \alpha_{\mathrm{O}} \mathrm{n}_{\alpha 0} \mathrm{~F}\right) J_{d e}^{f} /\left(J_{c e l l}\left(J_{d c}^{f}-J_{\text {cell }}\right)\right)$

and the third term is the membrane resistance $\left(\mathrm{R}_{\mathrm{m}}\right)$. The empirical equation of $\alpha_{\mathrm{O}}$ as a function of $\mathrm{RH}$ can be obtained by the following equation [15 and 23]:

$\alpha_{O}=0.6099 R H_{c}^{\text {inlet }}+0.0546$

As expressed in equation (32), $\alpha_{o}$ increases with RH. It is well known that $\alpha_{o}$ is a function of temperature, and follows Equation (32) [15, 23] at 100\% RH:

$\alpha_{O}=0.001678 T$

So, equation (29) could be written as Equation (35) [15, 23]:

$\alpha_{o}=\left(0.001552 R H_{c}^{\text {inlet }}+0.000139\right) T$ 
Equation (36) gives an empirical equation of $\alpha_{o}$ as a function of temperature and RH. $\alpha_{o}$ increases with increasing temperature and $\mathrm{RH}$. The apparent exchange current density (AECD) for $\mathrm{O}_{2}$ reduction reaction $\left(i_{O_{2}}^{O}\right)$ in equation (28) and (29) can be related to the cathode electrochemical $\mathrm{Pt}$ surface area $\left((\text { EPSA })_{C}, \mathrm{~m}^{2} / \mathrm{m}^{2}\right), \mathrm{O}_{2}$ inlet partial pressure $\left(P_{o_{2}}^{c-i n l e t}\right)$, and intrinsic exchange current density (IECD) $\left(J_{O_{2(P t)}}^{o}\right)$ by the following equation (37) [14]

$$
i_{O_{2}}^{o}=(E P S A) c J_{O_{2(P t)}}^{o}\left(\frac{P_{O_{2}}^{Q-i n l a t}}{P_{O_{2}}^{Q}}\right)^{\alpha_{Q}}
$$

The values of (EPSA)c, $P_{O_{2}}^{c-\text { inlet }}$, and $i_{O_{2}}^{O}$ can be experimentally measured, from the IECD that can be calculated as in table 1 [24].

Table 1 Measured and simulated kinetic parameters at $120^{\circ} \mathrm{C}, 1.0135 \mathrm{bar}$, with different inlet $\mathrm{RHs}$

\begin{tabular}{|c|c|c|c|c|}
\hline RH\% & $\operatorname{AECD}\left(\mathbf{A} / \mathbf{m}^{2}\right)$ & $\operatorname{EPSA}\left(\mathrm{m}^{2} / \mathrm{m}^{2}\right)$ & $P_{\mathrm{O}_{2}}^{-C \text {-average }}$ (atm) & $\operatorname{IECD}\left(\mathrm{A} / \mathrm{m}^{2}\right)$ \\
\hline & $8.6 \times 10^{-8}$ & 530 & & $7.97 \times 10^{-8}$ \\
\hline 70 & $6.3 \times 10^{-8}$ & $\begin{array}{l}50.9 \\
49.8\end{array}$ & $\begin{array}{l}0.00024 \\
0.10502\end{array}$ & $5.51 \times 10^{-8}$ \\
\hline 50 & $5.2 \times 10^{-8}$ & 46.4 & 0.12628 & $2.22 \times 10^{-8}$ \\
\hline 35 & $4.9 \times 10^{-8}$ & 42.9 & 0.14716 & $1.93 \times 10^{-8}$ \\
\hline 25 & $3.9 \times 10^{-8}$ & 36.0 & 0.16435 & $1.59 \times 10^{-8}$ \\
\hline
\end{tabular}

Nafion 112-based MEA.

\section{RESULTS and DISCUSSION}

This section presents the outcome of the model studying the effects of the incoming air transients to the fuel cell which are inlet (air pressure, air mass flow, air temperature, and relative humidity) these inputs of the fuel cell system, have their individual effects on the system outputs ( stack power, polarization curves and system efficiency). To obtain the V-I characteristics (polarization curve) of the PEM fuel cell, the model is simulated using MATLAB for the following values air pressure $\left(\mathrm{P}_{\text {air }}=\right.$ 1.0135: 15 bar), (air mass flow rate $\left(\dot{\mathrm{m}}_{\text {air }}=20: 50 \times 10^{-3} \mathrm{~kg} / \mathrm{s}\right)$, air temperature $\left(\mathrm{T}_{\text {cell }}=40: 80{ }^{\circ} \mathrm{C}\right)$ and air relative humidity $(\mathrm{RH}=30: 100 \%)$. The simulated V-I characteristics (polarization curve) of PEMFC system are shown in the following figures which depicts the various polarization losses. These polarization curves or V-I characteristic plots the cell voltage versus current density of a single cell, including the net power based and system efficiency.

The model studies the effect of each input alone and making the other inputs constants this effect is observed on the system outputs which will be illustrated in this section. The study is performed in two sections:

- Section I: With constant relative humidity.

- Section II: With vitiating relative humidity effect.

\subsection{Model Validation}

In order to validate the obtained results of the considered mathematical model, comparison of samples of the recent results with an experimental data of other researchers has been carried out. Figure (2) shows a comparison of obtained polarization curve with Chenge et al. [25] at 1.0135 bar, $50 \%$ and $\left(60,80{ }^{\circ} \mathrm{C}\right)$ for air pressure, air relative humidity and air temperature respectively, and air mass flow rate from $\left[(0.018\right.$ to 1.97$\left.) \times 10^{-3} \mathrm{~kg} / \mathrm{s}\right]$. It can be shown that there are reasonable agreement of the obtained mathematical results with that of the experimental data in both trends and values of 
the polarization curves. Effects of air parameters conditions on the performance characteristics for fuel cell stack are evaluated using the considered mathematical model.

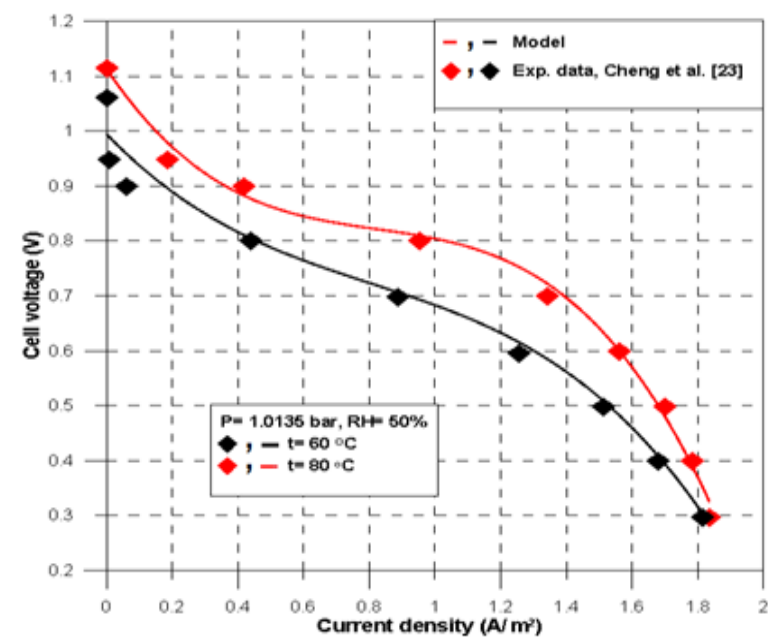

Fig 2; Comparison of obtained polarization curve with Chenge et al. experimental data [25], at different RH values.

\subsection{Outcomes with constant relative humidity effect}

\subsubsection{Air mass flow rate effect on fuel cell performance}

Figure (3) demonstrates the evaluated results of cell output voltage versus cell output current, which is the V-I characteristic curves (polarization curves) for different air mass flow rates at constant temperature of $60^{\circ} \mathrm{C}$. It is noticed that cell performance increases with the decrease of input air mass flow rate. The increasing behavior of variable air mass flow rate is almost the same effect with phase shift related to the increase of output cell current to a decrease in the output voltage.

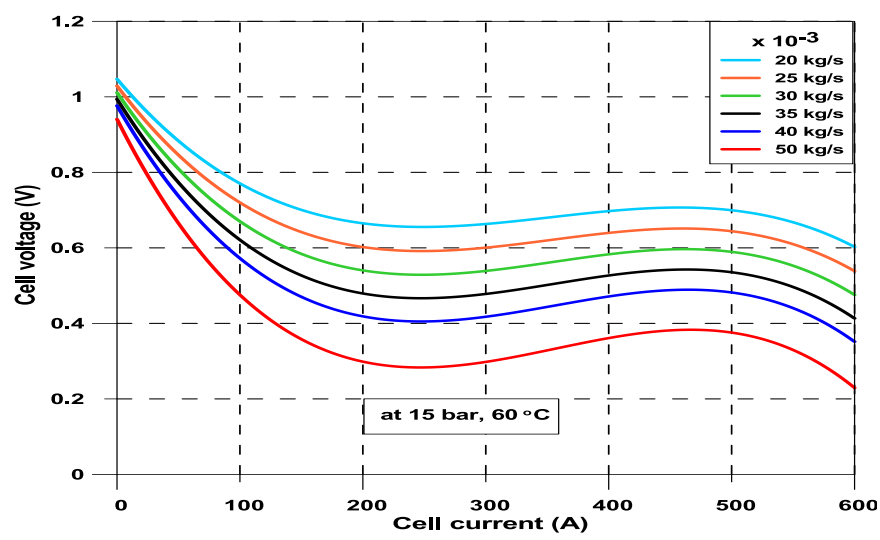

Fig 3; Fuel cell voltage versus cell current (polarization curves) for different air mass flow rates

\subsubsection{Pressure effect on fuel cell performance}

Figure (4) illustrates the obtained between output cell voltage versus output cell current which is the V-I characteristic curves or (polarization curves) that prescribe the fuel cell performance and relate the current (or current density) to the fuel cell voltage, for different air pressure values at constant temperature of $60^{\circ} \mathrm{C}$. It is noticed that cell performance increases with the increase of input air pressure. This increasing behavior of variable air pressure is almost the same effect with phase shift related to the increase of output cell current to a decrease in the output voltage. 


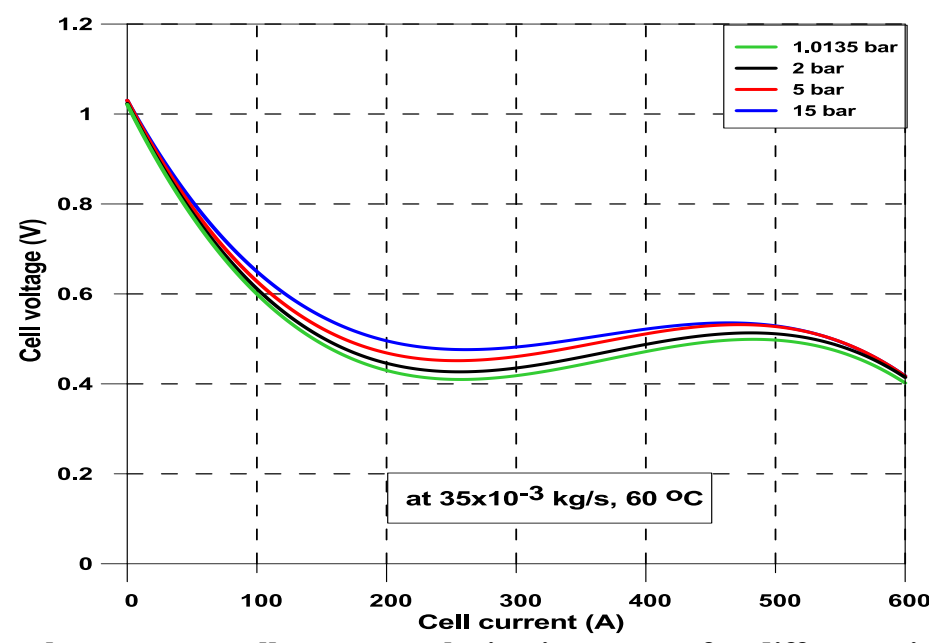

Fig 4; Fuel cell voltage versus cell current polarization curves for different air pressure value

\subsubsection{Air temperature effect on fuel cell performance}

Figure (5) illustrates the relation between output cell voltage (V) versus output cell current (A) which is the V-I characteristic curves or (polarization curves) that prescribe the fuel cell performance and relate the current (or current density) to the fuel cell voltage, for different air temperatures at constant air mass flow rate of $35 \times 10^{-3}(\mathrm{~kg} / \mathrm{s})$. It is noticed that cell performance increases with the increase of input air temperature. This increasing behavior of variable air temperature is almost the same effect with phase shift related to the increase of output cell current to a decrease in the output voltage.

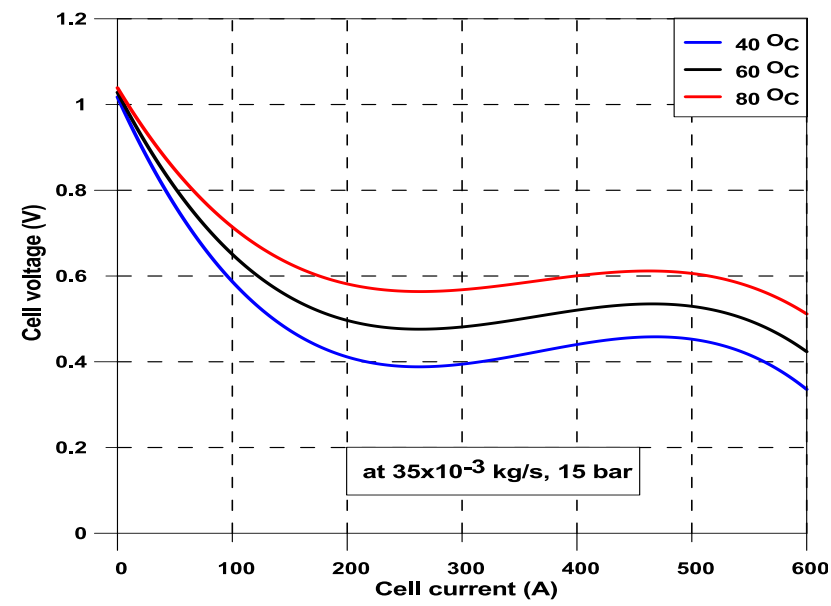

Fig 5; Fuel cell voltage versus cell current polarization curves for different air temperature values

Figure (6) illustrates the relation between output cell voltage versus output cell current, which is the V-I characteristic curves or (polarization curves) that prescribe the fuel cell performance and relate the current (or current density) to the fuel cell voltage, for different air temperatures at constant air pressure of 15 (bar). It is noticed that the performance increases with the increase of input air temperature. This increasing behavior of variable air temperature is almost the same effect with phase shift related to the increase of output cell current to a decrease in the output voltage this behavior is due to with the increase of air temperature the proton exchange in the membrane is increased as the chemical reactions increase. 


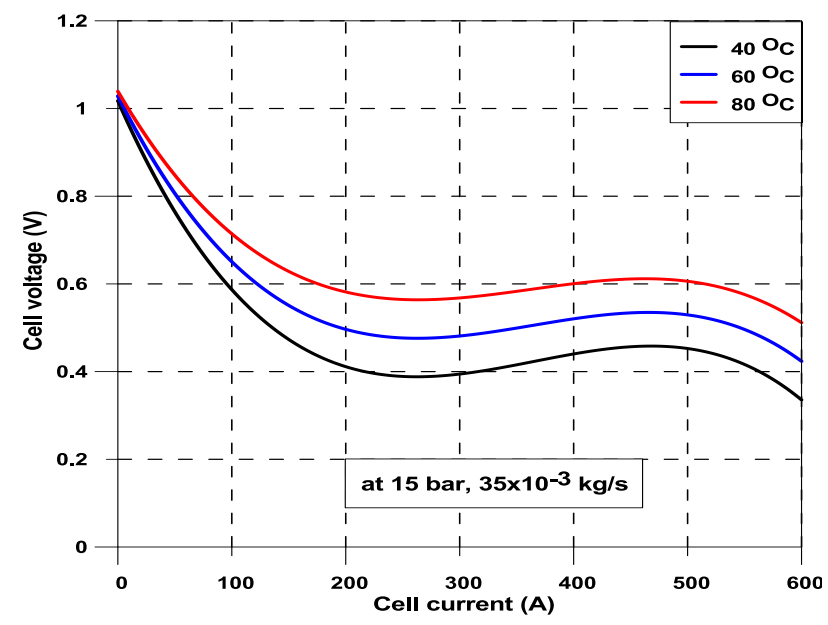

Fig 6; Fuel cell voltage versus cell current polarization curves for different air temperature values

\subsection{Outcomes with variating relative humidity effect}

Figure (7) presents the relation between output cell voltage versus output cell current, which is the V-I characteristic curves or (polarization curves) that describe the fuel cell performance and relate the current (or current density) to the fuel cell voltage. For different inlet relative humidity at constant air mass flow rate of $35 \times 10^{-3}(\mathrm{~kg} / \mathrm{s})$ and air temperature of $60\left({ }^{\circ} \mathrm{C}\right)$. It is noticed that cell performance increases with the increase of input air relative humidity. This increasing behavior of variable air relative humidity is almost the same effect with phase shift related to the increase of output cell current to a decrease in the output voltage as with the increase of relative humidity the water level in the membrane is increased which increases the electron transfer rate in the cell and increase cell productivity.

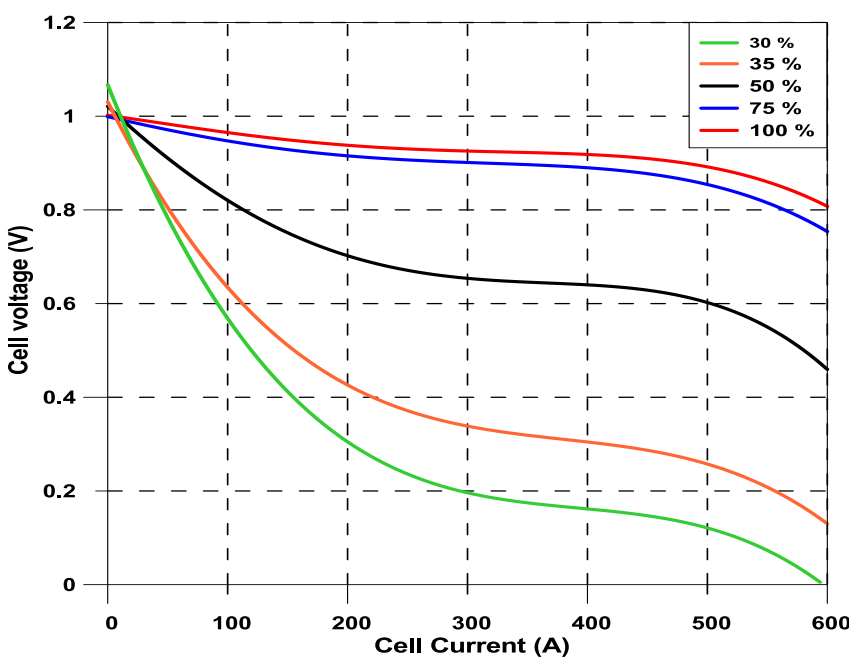

Fig 7; Fuel cell voltage versus cell current (polarization curves) for different relative humidity

\subsection{Optimization of fuel cell operating conditions}

This section illustrates the optimized fuel cell operating condition parameters obtained from the model. Figure (8) presents performance curves for cell power and efficiency versus current density for different air mass flow rates at constant air pressure 15 (bar) and air temperature $60\left({ }^{\circ} \mathrm{C}\right)$. As shown the optimum range were from $1.2 \times 10^{-4}\left(\mathrm{~A} / \mathrm{m}^{2}\right)$ current density where cell power and efficiency were $0.42\left(\mathrm{~W} / \mathrm{m}^{2}\right)$ and $21(\%)$ respectively at $50(\mathrm{~kg} / \mathrm{s})$, to $1.51 \times 10^{-4}\left(\mathrm{~A} / \mathrm{m}^{2}\right)$ current density where cell power and efficiency were $1.05 \times 10^{-4}\left(\mathrm{~W} / \mathrm{m}^{2}\right)$ and $53(\%)$ respectively at $20 \times 10^{-3}$ $(\mathrm{kg} / \mathrm{s})$. 


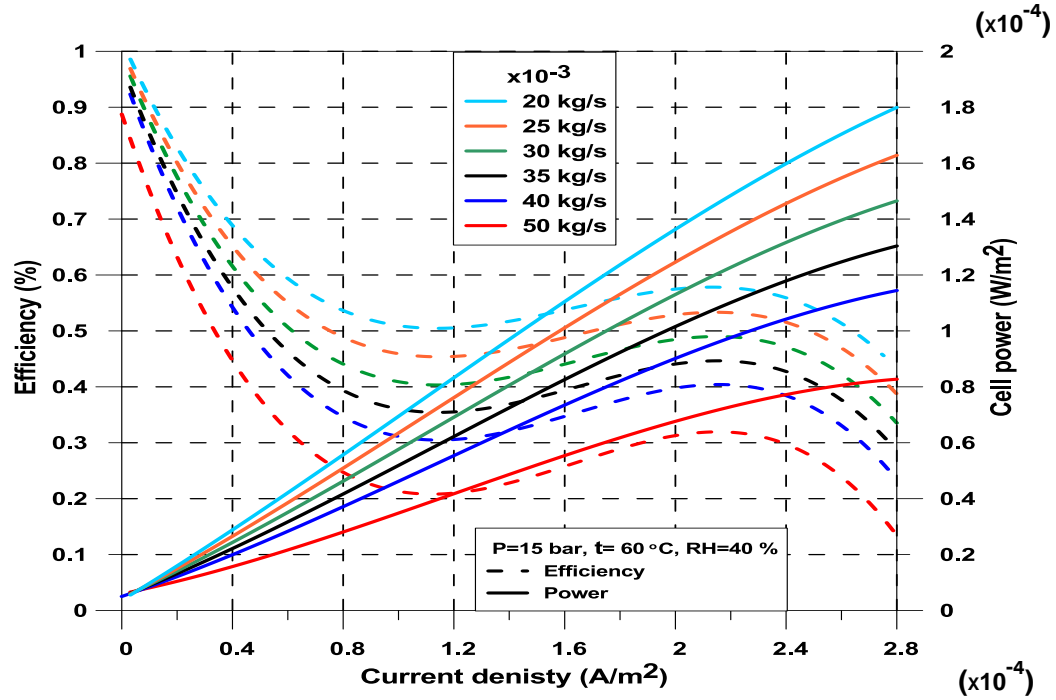

Fig. 8; Effect of air mass flow rate variation on fuel cell performance polarization curves

Figure (9) illustrates performance curves for cell power and efficiency versus current density for different air pressure values, at constant $35 \times 10^{-3}(\mathrm{~kg} / \mathrm{s})$ and $60\left({ }^{\circ} \mathrm{C}\right)$ for air mass flow rate and air temperature respectively. As shown the optimum range were from $1.49 \times 10^{-4}\left(\mathrm{~A} / \mathrm{m}^{2}\right)$ current density where cell power and efficiency were $0.67\left(\mathrm{~W} / \mathrm{m}^{2}\right)$ and $34(\%)$ respectively at 1.0135 (bar), to 1.51 $\mathrm{x} 10^{-4}\left(\mathrm{~A} / \mathrm{m}^{2}\right)$ current density where cell power and efficiency were $0.77 \times 10^{-4}\left(\mathrm{~W} / \mathrm{m}^{2}\right)$ and $39(\%)$ respectively at 15 (bar).

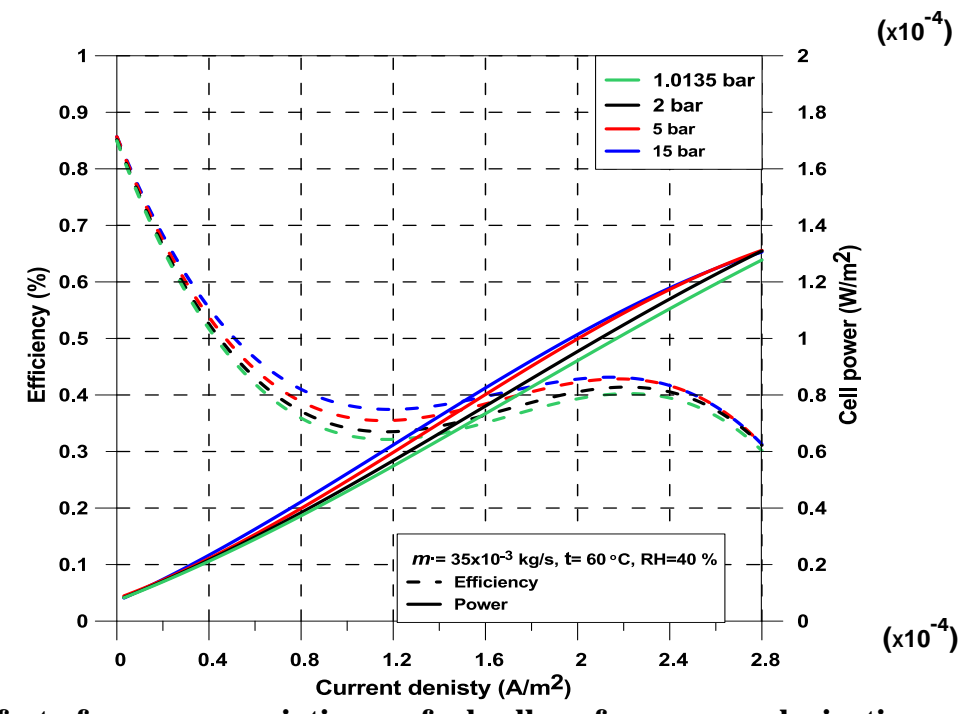

Fig. 9; Effect of pressure variation on fuel cell performance polarization curves

Figure (10) demonstrates performance curves for cell power and efficiency versus current density for different air temperature values, at constant $35 \times 10^{-3}(\mathrm{~kg} / \mathrm{s})$ and 15 (bar) for air mass flow rate and air pressure respectively. As shown the optimum range were from $1.47 \times 10^{-4}\left(\mathrm{~A} / \mathrm{m}^{2}\right)$ current density where cell power and efficiency were $0.63 \times 10^{-4}\left(\mathrm{~W} / \mathrm{m}^{2}\right)$ and $32(\%)$ respectively at $40\left({ }^{\circ} \mathrm{C}\right)$, to 1.55 $\times 10^{-4}\left(\mathrm{~A} / \mathrm{m}^{2}\right)$ current density where cell power and efficiency were $0.92 \times 10^{-4}\left(\mathrm{~W} / \mathrm{m}^{2}\right)$ and $46(\%)$ respectively at $80\left({ }^{\circ} \mathrm{C}\right)$. 


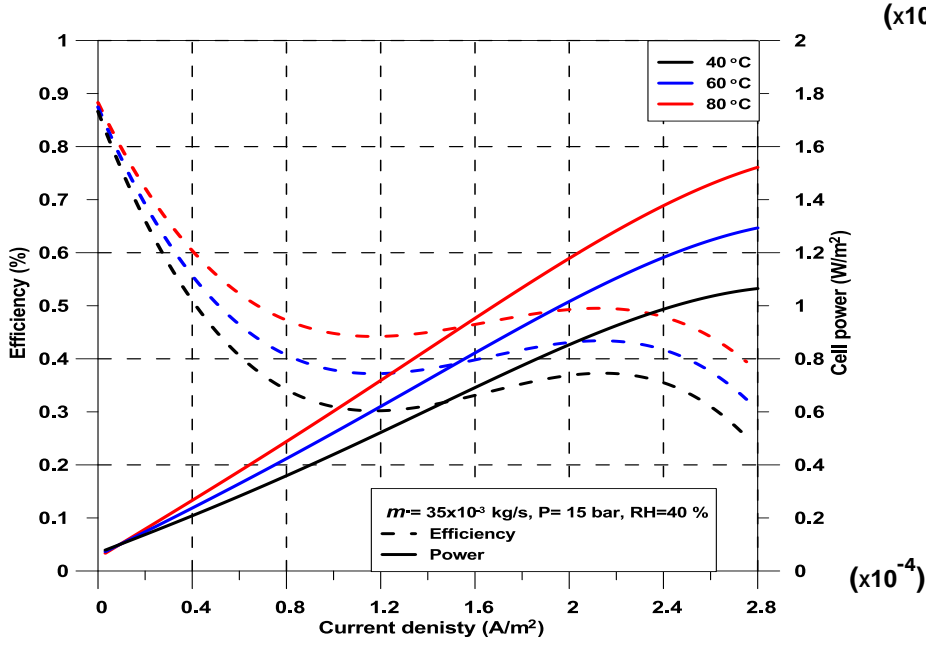

$\left(\mathrm{x} 10^{-4}\right)$

$\left(x 10^{-4}\right)$

Fig. 10; Effect of air temperature variation on fuel cell performance polarization curves

Figure (11) shows performance curves for cell power and efficiency versus current density for different air relative humidity values, at constant $35 \times 10^{-3}(\mathrm{~kg} / \mathrm{s}), 15$ (bar) and $60\left({ }^{\circ} \mathrm{C}\right)$ for air mass flow rate, air pressure and air temperature respectively. As shown the optimum range were from 2 $\times 10^{-4}\left(\mathrm{~A} / \mathrm{m}^{2}\right)$ current density where cell power and efficiency were $1.83 \times 10^{-4}\left(\mathrm{~W} / \mathrm{m}^{2}\right)$ and $74(\%)$ respectively at $100(\% \mathrm{RH})$, to $2.46 \times 10^{-4}\left(\mathrm{~A} / \mathrm{m}^{2}\right)$ current density where cell power and efficiency were $0.17 \times 10^{-4}\left(\mathrm{~W} / \mathrm{m}^{2}\right)$ and $7(\%)$ respectively at $30(\% \mathrm{RH})$.

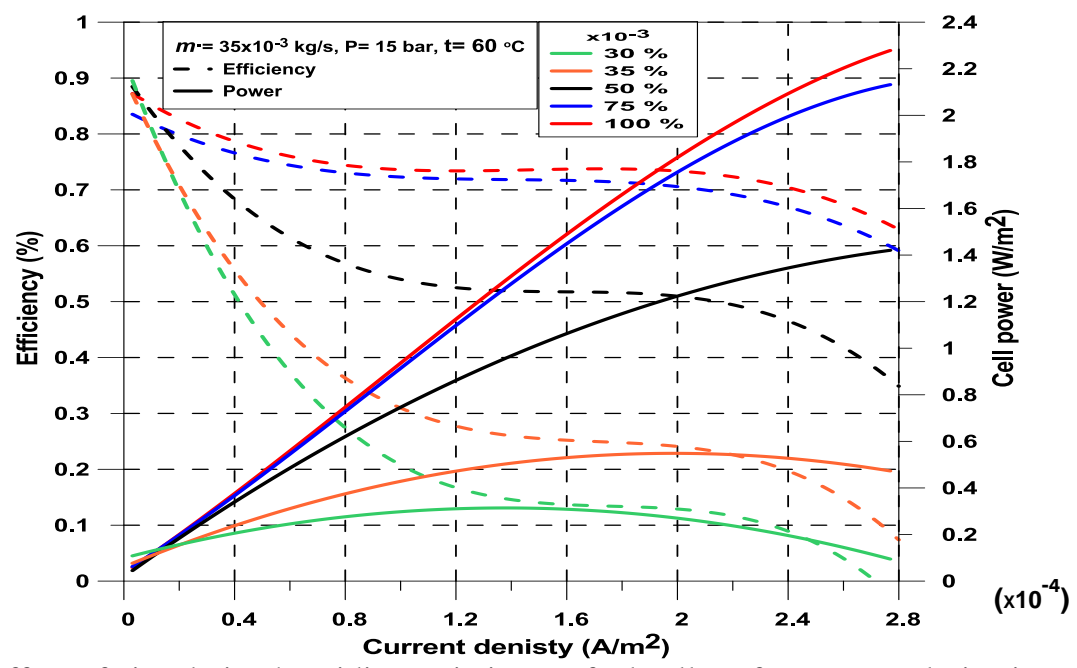

Fig 11; Effect of air relative humidity variation on fuel cell performance polarization curves

\section{CONCLUSION}

This paper discusses a model simulation to measure the fuel cell performance; from the previous figures found that with the increase of air pressure the fuel cell performance increases. The performance decreases with increasing air mass flow rate. The more the cell temperature increases the fuel cell performance increases. The cell temperature has limits which are required for the fuel cell reactions to be performed and to maintain the required humidity inside the fuel cell; cell temperature ranges from $60^{\circ} \mathrm{C}$ to $80^{\circ} \mathrm{C}$ for this type for fuel cells the Proton exchange membrane fuel cell (PEMFC). Inlet air relative humidity proved to be an effective parameter affecting fuel cell performance which is necessary for cell reactions as relative humidity increases it also increases the fuel cell performance. The percentage of relative humidity is so important affecting water management inside the fuel cell for that if the percentage is high it causes the cell to flood out, and if the percentage is low it may cause the cell to dry out, in each case reducing the cell membrane reactions which leads to a drop is fuel cell performance. 
The most preferred air operating conditions for a PEMFC designed to power an electric vehicle may be as follows:

- Air pressure at 5 bar.

- Air mass flow rate at $35 \times 10^{-3} \mathrm{~kg} / \mathrm{s}$.

- Air temperature at $60{ }^{\circ} \mathrm{C}$.

- Air relative humidity at $75 \%$.

Those are the best operating parameters which the fuel cell need to generate the necessary power for an electric engine of a vehicle without the risk of being flooded or dry out which leads to a drop in the fuel cell performance.

\section{REFERENCES}

[1] M. Ogburn, D. Nelson, K. Wipke, and T. Markel., "Modeling and Validation of a Fuel Cell Hybrid Vehicle", Mechanical Engineering, Virginia Tech, US, ISSN 01-1566, (2000).

[2] Ferguson and V. Ugursal., "A Fuel Cell Model for Building Cogeneration Applications", Canadian Residential Energy End-use Data and Analysis Centre Halifax, Nova Scotia, Canada, B3J 1B6, (2002).

[3] J. Bird., " Model of the Air System Transients in a Fuel Cell Vehicle", Faculty of Virginia Polytechnic Institute and State University, (2002).

[4] M. Nielsen, M. Bang and I. Bach, "Modeling of Thermodynamic Fuel Cell Systems", Aalborg University Institute of Energy Technology, Denmark, (2002).

[5] S. Tao, et al Y. Si-jia, C. Guang-yi, \& Z. Xin-jian, " Modeling and control PEMFC using fuzzy neural networks", Journal of Zhejiang University Science, 6A(10):1084-1089, (2005).

[6] Y. Si-jia, S. Tao C. Guang-yi, and Z. Xin-jian, "Modeling and Control of PEMFC Using Fuzzy Neural Networks", Journal of Zhejiang University Science, China, ISSN 1009-3095, 6A(10):1084-1089, (2005).

[7] C. Spiegel," Mathematical modeling of polymer exchange membrane fuel cells" University of South Florida, (2008).

[8] R.Seyezhai \& B.L.Mathur, "Mathematical Modeling of Proton Exchange Membrane Fuel Cell", Tamilnadu, India, International Journal of Computer Volume 20, No.5, pp 0975 - 8887, (2011).

[9] C. Ziogou, S. Voutetakis, S. Papadopoulou, M. C. Georgiadis, " Modeling, Simulation and Experimental Validation of a PEM Fuel Cell System", Chemical Process Engineering Research Institute, Greece, Journal of Computers and Chemical Engineering, 35, pp. 1886 - 1900, (2011).

[10] V. Boscaino, R. Miceli, and Giuseppe Capponi, "MATLAB-Based Simulator of a 5 kW Fuel Cell for Power Electronics Design", University of Palermo, Department of Energy, Italy, International Journal of Hydrogen Energy, 38, pp. 7924 - 7934, (2013).

[11] M.G. Santarelli, M.F. Torchio, and P. Cochis, "Parameters Estimation of a PEM Fuel Cell Polarization Curve and Analysis of Their Behavior with Temperature", Department of Energetic, Italy, Journal of Power Sources, 159, pp. 824-835, (2006).

[12]H. Zhao, and A. F. Burke," Optimization of Fuel Cell System Operating Conditions for Fuel Cell Vehicles", Institute of Transportation Studies, University of California, USA , Journal of Power Sources, 186, pp. 408-416, (2009).

[13] S. Shimpalee, S. Dutta, W. K. Lee, and J. W. Van Zee, "Effect of Humidity on Fuel Cell Performance", University of South Carolina Columbia, Proceedings of ASME IMECE, Nashville, TN, HTD, 364(1), pp. 367 - 374 (1999).

[14] C. Song, Y. Tang, J.L. Zhang, J. Zhang, H. Wang, J. Shen, S. McDermid, J. Li, P. Kozak, Electrochim. Acta 52 (2007) 2552.

[15] J. Zhang, Y. Tang, C. Song, J. Zhang, H. Wang, J. Power Sources 163 (2006) 532.

[16] Hirschenhofer, J.H., D.B. Stauffer, R.R. Engleman, and M.G. Klett. Fuel Cell Handbook. Morgantown, WV: U.S. Department of Energy - Department of Fossil Energy, (1998).

[17] Geyer, H.K. and Ahluwalia, R.K. ANL Report \#98-8. Argonne National Lab, (1998).

[18] Alex. Kabza., " Just Another Fuel Cell Formulary", (2013).

[19] www.faqs.org/faqs/meteorology/temp-dewpoint/.

[20] http://hyperphysics.phyastr.gsu.edu/hbase/hframe.html.

[21] J. Zhang, Y. Tang, C. Song, Z. Xia, H. Liu, H. Wang, J. L. Zhang. Electrochimica Acta 53 (2008) 5315-5321.

[22] J.C. Amphlett, R.M. Baumert, R.F. Mann, B.A. Peppley, P.R. Roberge, T.J. Harris, J.Electrochem. Soc. 142 (1995).

[23] http://hyperphysics.phyastr.gsu.edu/hbase/kinetic/watvap.html.

[24] Y. Tang, J. Zhang, C. Song, H. Liu, J. Zhang, H. Wang, S. Mackinnon, T. Peckham, J. Li, S. McDermid, P. Kozak, J. Electrochem. Soc. 153 (2006) A2036. 
[25] S. J. Cheng, J. M. Miao, and S.J. Wu, "Investigating the Effects of Operational Factors on PEMFC Performance Based on CFD Simulations Using a Three-Level Full-Factorial Design", Department of Power Mechanical Engineering, Army Academy, Taiwan, Journal of Renewable Energy, 39, pp. 250-260, (2012).

[26] J. L. Zhang, Y. Tang, C. Song, X. Cheng, J.Zhang, H. Wang. Electrochimica. Acta 52 (2007) 5095-5101.

[27] H. Zhang, M. Jin, Y.Xia. Electronic supplementary material for (ESI) the royal society of chemistry (2012).

[28] Pilatowsky, I.; Romero, R.J.; Isaza, C.A.; Gamboa, S.A; Sebestian, P.J.; Rivera, W. " Cogeneration Fuel Cell Sorption Air Conditioning Systems", XIV, 160p. 55 illus.., Hardcover, (2011).

[29]Zhang. J. (Ed.), "PEM Fuel Cell Electrocatalysts and Catalyst Layers Fundamentals and Applications", 2008, XXI, 11137 p, Hardcover.

[30] J.-H. Jang, W.-M. Yan, H.-Y. Li, Y.-C. Chou, J. Power Sources 159 (2006) 468.

[31]H. Xu, H.R. Kunz, J.M. Fenton, Electrochim. Acta 52 (2007) 3525.

[32] R. Jiang, H. Russell Kunz, J.M. Fenton, Electrochim. Acta 51 (2006) 5596.

[33] M.M. Saleh, T. Okajima, M. Hayase, F. Kitamura, T. Ohsaka, J. Power Sources 164 (2007) 503.

[34] T. Abe, H. Shima, K. Watanabe, Y. Ito, J. Electrochem. Soc. 151 (2004) A101.

[35] R. Jiang, H.R. Kunz, J.M. Fenton, J. Power Sources 150 (2005) 120.

[36] H. Xu, Y. Song, H.R. Kunz, J.M. Fenton, J. Electrochem. Soc. 152 (2005) A1828.

[37] F.A. Uribe, T.E. Springer, S. Gottesfeld, J. Electrochem. Soc. 139 (1992) 765.

[38] M. Ciureanu, J. Appl. Electrochem. 34 (2004) 705.

[39]EG\&G Technical Services, Inc., "Fuel Cell Handbook" (Seventh Edition), National Energy Technology Laboratory Morgantown, West Virginia, (2004). 